\title{
THE STATE OF ECONOMIC KNOWLEDGE AND ITS IMPORTANCE IN THE OPINION OF YOUNG POLES
}

\author{
ANETA SOKÓ $\_,{ }^{1}$ IRENA FIGURSKA ${ }^{2}$ \\ ${ }^{1}$ University of Szczecin, Faculty of Management and Economics of Services, POLAND \\ e-mail: aneta.dorota@wp.pl \\ ${ }^{2}$ Pomeranian University in Slupsk, Faculty of Social Sciences, POLAND \\ e-mail: irenafigurska@vp.pl
}

RECEIVED

ACCEPTED

JEL

CLASSIFICATION

KEYWORDS

ABSTRACT
6 November 2018

3 December 2018

D81, D83

knowledge; economic knowledge; management; process; decision making

Economic knowledge is a sub-discipline of the economics of knowledge. Over the past decade, its importance has increased due to the turbulence of the environment and its impact on economic processes. Lack of or insufficient economic knowledge limits the ability of economic entities to make the right decisions therefore such knowledge becomes a more and more desired resource by them. In connection with the above, an attempt was made to examine the level of economic knowledge of young Poles from the $Z$ generation and to analyze economic knowledge as a determinant of economic decisions. The main research goal is: By using scientific procedures and applying the appropriate methodology, examine and know the level and the role of economic knowledge, which in the students' opinion it has the greatest impact on making proper economic decisions. The above considerations became the basis for formulating the following research hypothesis: Economic knowledge determines the rationality of economic decisions. To achieve the formulated goal and verify the research hypothesis, focus studies on the group of students of economics and psychology were carried out.

\section{Introduction}

The economy of the 21 st century is characterized by dynamism, volatility as well as uncertainty and risk. The rapidly changing conditions of competition in the local and global environment have caused the need to present an active attitude manifested by taking action in response to these changes. In this process, non-material factors such as knowledge, and especially economic knowledge, play a significant role. Having such knowledge 
creates conditions conducive to creating value added by its owners. In order to make the right economic decisions, communities should be focused on increasing knowledge in this area. Therefore, in order to show a certain scientific area and subject it to analysis, the article distinguishes two trends. The first, having an exploratory character, is focused on the analysis of the foreign and Polish literature devoted to knowledge. These studies made it possible to critically analyze and shape the research framework. In particular, they concerned knowledge as a resource and a specific type of knowledge, namely economic knowledge. The second trend focuses on the research on the state of economic knowledge and its importance for making the right decisions. The study took the form of focused group interviews.

\section{The essence of knowledge}

From ancient times knowledge has been a subject matter of interest among scholars, mainly philosophers, who have tried to define and investigate its nature. It suffices to mention a few relatively well-known sayings related to knowledge, which are attributed to outstanding figures of science:

1. Human behaviour flows from three main sources: desire, emotion, and knowledge (Plato).

2. Real knowledge is to know the extent of one's ignorance (Confucius).

3. A good decision is based on knowledge and not on numbers (Plato).

4. True knowledge exists in knowing that you know nothing (Socrates).

5. Having knowledge but lacking the power to express it clearly is no better than never having any ideas at all (Pericles).

6. The natural desire of good men is knowledge (Leonardo da Vinci).

7. To know that we know what we know, and to know that we do not know what we do not know, that is true knowledge (Nicolaus Copernicus).

Knowledge has become widely appreciated and treated as the most important determinant of competitiveness (of people, organizations, societies) only in a knowledge-based economy (Kowalczyk, Nogalski, 2007, pp. 33-40; Figurska, 2012, pp. 75-83; Figurska, 2014, pp. 36-39). However, until today the one definition of knowledge that would be the generally accepted by both scientists from various fields of science and business practitioners, has not been developed. Definitions proposed by various authors connect knowledge with information, experience or learning, perceive it as a reflection of reality in the human mind or as a confirmed conviction (see: Probst, Raub, Romhardt, 2002; Liebeskind, 1996, p. 94; Tiwana, 2003, pp. 63-64; Wiig, 1999, p. 33; Mikuła, 2006, pp. 106-108; Kowalczyk, Nogalski, 2007, p. 21). For the purpose of this article, knowledge is understood as "a fluid mix of framed experience, values, contextual information and expert insight that provides a framework for evaluating incorporating new experiences and information. It originates and is applied in the minds of knowers. In organizations, it often becomes embedded not only in documents or repositories but also in organizational routines, processes, practices, and norms" (Davenport, Prusak, 1998, p. 5).

In practice, people often identify information with knowledge, which is a mistake and testifies to a misunderstanding of the essence of knowledge. Information consists of qualitative or quantitative data which is essentially and logically systematized by using methods such as: contextualization, categorization, calculation, correction and condensation. Appropriately structured, processed, understood as well as subjectively and individually interpreted information transforms into knowledge. Information can be turned into knowledge with the use of different methods, including primarily: comparison, consequences, connections and conversation (Davenport, Prusak, 1998, pp. 3-5). In the 
process of transition from information to knowledge, context plays a significant role. Therefore, the distinction between information and knowledge is subjective, ambiguous and often difficult to perform (Figurska, 2014, p. 39). Knowledge is a specific resource because it (Mikuła, 2006, p. 109; Grudzewski, Hejduk, 2005, p. 48; Figurska, 2012, pp. 29-38; Fazlagić, 2014, pp. 64-66):

- has a dominant nature with respect to other resources,

- is inexhaustible and difficult to be fully used,

- is immaterial and elusive,

- is relative and ambiguous,

- increases and gains value if used in practice,

- can be used at the same time in various places and by many people,

- cannot be measured with traditional economic measures,

- can be created with the use of various methods,

- is reflected in technologies, procedures, documentation, databases, employees' competencies etc.,

- is manifested in products and services,

- becomes out-of-date quickly,

- is not the "amount" of knowledge that determines its usefulness but its' appropriateness to the situation in which it is to be used.

The features of knowledge as a resource determine the specificity of actions undertaken on knowledge and on the basis of knowledge.

Skillfully developed and used in activities knowledge enables making the right decisions and actions, increases the effectiveness of undertaken actions, accelerates the reaction to changes taking place in the widely understood environment, decreases the level of uncertainty in risky ventures, facilitates building and maintaining professional relations, increases the individuals' creativity and innovativeness, and positively affects their self-esteem resulting from the fact of being perceived and appreciated as a professional (Figurska, 2012, pp. 82-83).

\section{Knowledge types}

Knowledge is not a homogeneous resource, therefore various classifications of knowledge based on different criteria are described in the literature. "These classifications enable people to better understand the nature and complexity of knowledge which in turn facilitates the process of choosing appropriate methods and tools of creating and using knowledge in practice for the organization's benefit" (Figurska, 2014, p. 39).

The classification, which became the basis for development of many other classifications, divides knowledge into tacit and explicit (see: Polanyi, 1966, pp. 4-25; Sveiby, 1997; de Jong, Ferguson-Hessler, 1996, pp. 105-113; Głuszek, 2004, pp. 73-74; Figurska, 2012, pp. 39-54; Jashapara, 2006, pp. 69-70). Tacit knowledge is located in people's minds, and is difficult to be both expressed with words, numbers, formulas, charts etc. and transferred to others. It consists of skills, experience, moral principles, level of sensitivity, intuition and beliefs and other individual and subjective components. Explicit knowledge, in turn, is located in procedures, verbal descriptions, books, patents, technical documentation, manuals, databases, archives etc., and it can be relatively easily expressed and transferred.

In addition to tacit and explicit knowledge, M. Bratnicki describes cultural knowledge, which consists of convictions, norms and values used by people in the process of assessing the value and significance of incoming 
information. This type of knowledge, just like tacit knowledge, is contained in brains of people, while explicit knowledge is contained in the organization when people left it (Bratnicki, 2000, pp. 35-36).

B. Lundvall and B. Johnson (1994, pp. 23-42) propose another classification, according to which knowledge can be divided into following types:

- know what - refers to facts and is about data and information,

- know how - refers to the ability of performing specific tasks and activities,

- know why - refers to rules and laws existing in science,

- know who - refers to specialists possessing important knowledge,

- know where and know when - refer to important market information.

Knowledge is also divided into individual and collective (Probst, Raub, Romhardt, 2002, pp. 155-156). Individual knowledge is an attribute of the person, because every human being possesses own, deep or superficial, general or specialist, tacit and explicit knowledge. A sum of individual knowledge of members of the team, department, organization etc., increased through their ability to cooperate, constitute a collective (social) knowledge.

By combining the division of knowledge into individual and social knowledge with the division into explicit and tacit knowledge, conscious knowledge (individual explicit, concerning facts, concepts and theories stored in the personal memory, notes, files etc.), automatic knowledge (individual tacit, taking a form of skills, practices coded in the mind and habits), objectified knowledge (social explicit, contained in instructions, hints and standards) as well as collective knowledge (social tacit, referring to existing routines) can be distinguished (Spender, 1996, p. 52).

Another type of knowledge, namely practical knowledge, is defined as a "blend of explicit and tacit procedural knowledge with explicit and tacit practice" (Guzman, 2009, p. 92). Practical knowledge consists of both explicit and tacit dimension, and it is constituted by both knowledge and practice (Figure 1).

\begin{tabular}{c|c|c|c|c|}
\multicolumn{1}{c}{ Explicit } & \multicolumn{2}{c}{ Tacit } \\
\cline { 2 - 5 } $\begin{array}{c}\text { Procedural } \\
\text { knowledge }\end{array}$ & KNOW-HOW & 1 & 2 & \\
\cline { 2 - 5 } Practice & $\begin{array}{l}\text { EXPLICIT } \\
\text { PRACTICE }\end{array}$ & $\mathbf{3}$ & $\mathbf{4}$ & $\begin{array}{r}\text { TACIT } \\
\text { PRACTICE }\end{array}$ \\
\cline { 2 - 5 } & $\begin{array}{c}\text { Explicit practical } \\
\text { knowledge }\end{array}$ & \multicolumn{3}{c}{$\begin{array}{c}\text { Tacit } \\
\text { practical knowledge }\end{array}$}
\end{tabular}

Figure 1. Taxonomy of practical knowledge

Source: Guzman (2009), p. 90.

The explicit component of procedural knowledge refers to know-how, whereas the tacit component, which includes concepts, ideas and experience, is usually unconsciously and automatically applied while performing a specific action. Practice is explicit when explicit knowledge is applied intentionally and a person is able to explain how the action is done. Practice is tacit when tacit knowledge is used while performing the action and the individual is unable to explain how this action is done (see Eraut, 2000, pp. 123-130).

Although nowadays knowledge is considered to be one of the main determinants of the competitiveness of individuals, not every type of knowledge influences this competitiveness to the same extent. Core knowledge 
enables conducting a given activity, but it doesn't influence a competitive advantage of a given unit. Advanced knowledge distinguishes a given unit from others and enables it to compete effectively on the market. Innovative knowledge, in turn, enables a given unit to achieve a competitive advantage on the market and to set new standards on the market (Tiwana, 2003, pp. 124-125) With time, innovative knowledge becomes advanced knowledge and finally goes to the level of core knowledge.

Depending on what a specific knowledge concerns, many knowledge types such as medical knowledge, legal knowledge, technical knowledge, economic knowledge etc. can be distinguished.

Summing up, described above classifications of knowledge have been created on the basis of different criteria. However, they are not mutually separable. For example, the subject of interest may be conscious (individual explicit) economic knowledge about the functioning of the money market or objectified (collective, explicit) technical knowledge etc. (Figurska, 2014, p. 42).

\section{Assessment of the state of economic knowledge - resullts of the research}

The article presents own research on economic knowledge The research area of this article includes both theoretical (literature studies) and empirical (conducted focused group interviews) analysis of the subject.

The application of appropriate scientific methods and procedures has allowed to define the concept of economic knowledge and to identify its impact on economic decisions taken by young Poles from the generation $Z$.

The following methods were used in the research: analysis, synthesis, induction and deduction. The conclusion for the conducted research has been the answer to the following research questions: What is the level of economic knowledge of young Poles from the $Z$ generation? and: Does economic knowledge determine economic decisions of study participants?

Consequently, the following hypothesis was put forward: 1. economic knowledge determines the rationality of economic decisions.

In qualitative research, focused group interviews ( $F G I)$ were conducted. In the framework of the discussion, phenomena related to the issue of economic knowledge and its significance for the rationality of decision making were analyzed.

Focused group interviews were conducted in October 2018 among young people studying in the first year of economics (first group) and psychology (second group). The research covered subjects aged 19 to 20 years. The first group consisted of 8 people (including 5 women), the second group consisted of 9 women.

Further considerations on economic knowledge entails defining this concept. Economic knowledge is a specific type of knowledge which includes knowledge of basic economic concepts (e.g. money, inflation, demand, etc.), understanding the relationship between these concepts, knowledge of current economic realities and the ability to apply possessed knowledge in practice (see: Roland-Lévy, 2004; Zaleśkiewicz, 2011; Kołodziej, 2011).

At the beginning of the research, participants of the discussion were asked about the role of knowledge in human life. In the group of future economists, participants of the discussion indicated that knowledge gives: greater awareness of the world, better understanding of the world, as well as the possibility of discussing topics in which people could not express their opinions if they did not have knowledge (in this case knowledge in a specific field was indicated). On the other hand, in the group of future psychologists, the participants of the research defined the role of knowledge as: the ability to understand a lot of issues, improved skills as well as protection before making mistakes. One of the participants defined knowledge as a source of: economic development, progress and innovation. 
Then the respondents were asked if they think that knowledge they have is the source of their personal development for them, and what kind of knowledge they value most. One participant in the discussion said that the knowledge he acquires by learning, studying and working is a source of development for him. Another person said that knowledge has always been important to her because acquiring knowledge shapes her personality, allows her to have own views, and besides, it enables her to acquire a specific profession.

Another area of discussion referred to the sources from which participants of the study draw knowledge (general, specialist, professional). Most of them pointed to the Internet as their main source of knowledge, followed by traditional sources, such newspapers and books. When participants of the discussion were asked about explanation, why they put the Internet in the first place among the sources of knowledge, they indicated its universal availability. However, they were aware that the Internet is not always reliable source of information and knowledge.

Then, the respondents were asked about their understanding of a term "economic knowledge". Future psychologists said that it is knowledge about how the economy works, how economic processes take place, how to rationally make economic decisions. In turn, representatives of future economists believed that it is the ability to use this knowledge to solve economic problems and make the right economic decisions.

The respondents were also asked if they could list the sources from which they would gain economic knowledge related to the functioning of a specific organization. In this case future economists turned out better in the discussion, listing: company websites, conferences, bulletins, studies, reports and brochures, whereas a group of future psychologists primarily listed reports and websites.

Another discussed issue was related to knowledge sharing. A third of people who took part in the discussion in both groups indicated that information exchange between individuals is quite effective, while the others declared cooperation in the group and the opportunity to knowledge sharing.

Next, participants of the research were asked to indicate barriers related to knowledge sharing at the university. Respondents' answers are presented in Table 1.

Table 1. Barriers related to knowledge sharing (ranked according to the degree of importance)

Specification

\footnotetext{
1. A society that promotes the knowledge of an individual, not a group

2. University culture that promotes individual knowledge, not teamwork and knowledge sharing in groups

3. Ignorance about a specific topic

4. Lack of time to transfer knowledge to others

5. Lack of knowledge searching skills
}

Source: own study based on the research.

Then the participants of the research were asked if they were interested in new knowledge about the latest economic trends. In response to this question, the three representatives of future psychologists stated that they did not have economic knowledge at all and showed no interest in current economic knowledge. Four people studying psychology and two people studying economics declared having some knowledge on the subject, but they believed that it did not concern their profile of studies, or they considered that at the moment they are just developing their interests in this field. The three future economists said "I know and I am interested in new knowledge about the 
latest economic trends", while the remaining group of people participating in the discussion replied that they know and use all new economic information.

Then, the level of economic knowledge of the study participants was examined. According to the authors, the obtained results are at a satisfactory level. When subjectively assessing a level of their own knowledge on various economic issues, the respondents gave positive answers many times. Detailed results are presented in Figure 2.

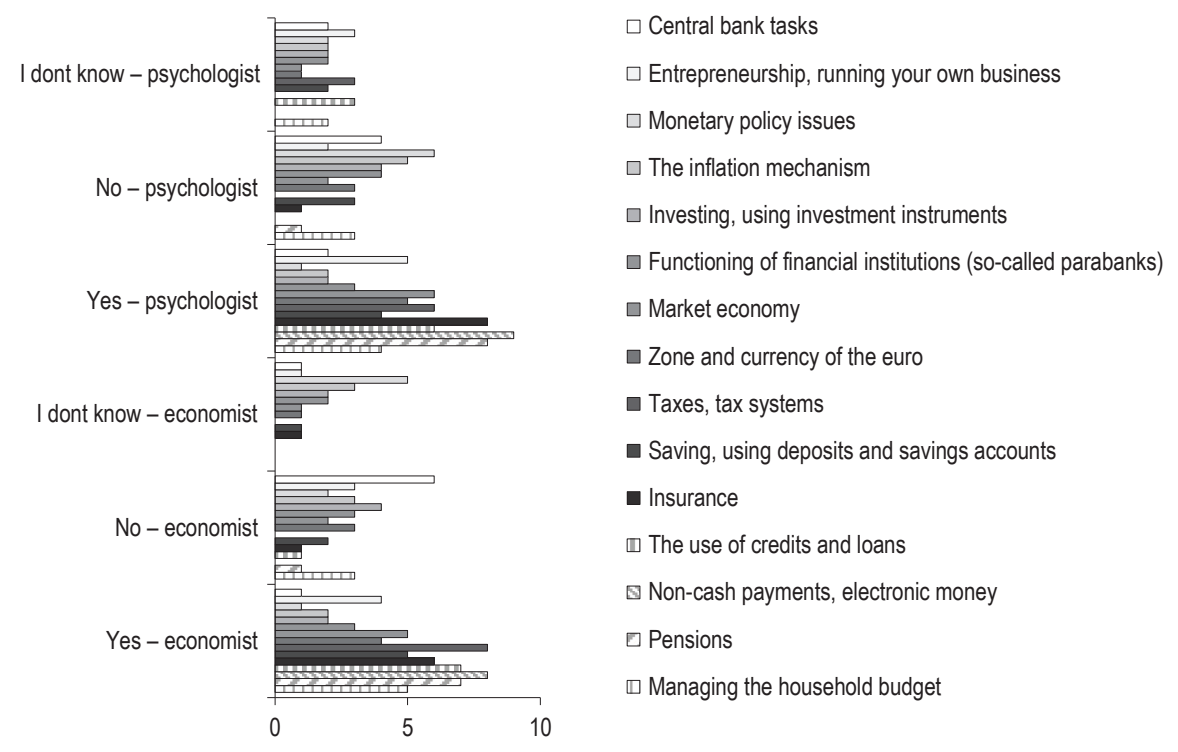

Figure 2. How would you rate the level of your economic knowledge and skills related to specific economic issues?

Source: own study based on research.

A more detailed analysis of the distribution of these responses was then made in relation to the answers given to other questions. Therefore, the last criterion that has been taken into account is the concrete state of knowledge in the field of defining economic concepts. The respondents were asked to give definitions of following terms: loan, deposit, tax, bank account, inflation, exchange rates and enterprise. The distribution of responses showed that most of terms mentioned above were understood by the research participants. The problem appeared when interpreting such issues as: investing, using investment instruments, the inflation mechanism, monetary policy issues, central bank tasks.

Summing up the results of the research, it is worth noting that the participants of the research in their first year at the university, regardless of the field of study, showed a satisfactory level of economic knowledge. This is a satisfying result and at the same time interesting from the point of view of economic development.

\section{Conclusions}

Economic knowledge as a research category is insufficiently examined, both theoretically and empirically. This concept is rarely studied, thus it inspires researchers to identify further scientific areas and to contribute 
to the development of this issue. The analyses presented in the subject literature, refer to quantitative as well as qualitative research. Although the latter are rarely carried out, their application may enhance the empirical knowledge obtained thanks to analytical studies. This was also done in this study, in which focus group interviews were used. The conclusions obtained in both research groups allowed to achieve the assumed goal, which was to know the current state of economic knowledge and its importance in the process of making decisions. The analysis of the state of economic knowledge made it possible to conclude that the level of this knowledge among the young generation of Poles is satisfactory.

\section{References}

Bratnicki, M. (2000). Podstawy współczesnego myślenia o zarządzaniu. Dąbrowa Górnicza: Wydawnictwo Triada.

Davenport, T.H., Prusak, L. (1998). Working knowledge: how organizations manage what they know. Boston: Harvard Business School Press.

de Jong, T., Ferguson-Hessler, M. (1996). Types and qualities of knowledge. Educational psychologist, 31 (2), 69-70.

Eraut, M. (2000). Non-formal learning and tacit knowledge in professional work. British Journal of Educational Psychology, 70, 123-130.

Fazlagić, J. (2014). Innowacyjne zarządzanie wiedzą. Warszawa: Difin.

Figurska, I. (2012). Zarządzanie wiedzą w organizacji. Słupsk: Wydawnictwo WHSZ.

Figurska, I. (2014). Knowledge as an attribute of the organization in the knowledge-based economy. In: E. Matuska, A. Sokół (eds.), Attributes of modern organization. Creativity-knowledge-innovation-trust (pp. 36-39). London: Scemcee Publishing.

Głuszek, E. (2004). Zarządzanie zasobami niematerialnymi przedsiębiorstwa. Wrocław: Wydawnictwo Akademii Ekonomicznej.

Grudzewski, W.M., Hejduk, I. (2005). Zarządzanie wiedzą w organizacjach. E-mentor, 1 (8). Retrieved from: http://www.e-mentor.edu. pl/artykul/index/numer/8/id/115.

Guzman, G. (2009). What is practical knowledge? Journal of Knowledge Management, 13 (4), 86-98.

Jashapara, A. (2006). Zarządzanie wiedzą. Warszawa: PWE.

Kołodziej, S. (2011). Wiedza ekonomiczna i postawy wobec podatków dorosłych Polaków. Studies \& Proceedings of Polish Association for Knowledge Management, 40, 192-201.

Kowalczyk, A., Nogalski, B. (2007). Zarządzanie wiedzą. Koncepcja i narzędzia. Warszawa: Difin.

Liebeskind, J.P. (1996). Knowledge, strategy and the theory of the firm. Strategic Management Journal, 17 (Winter Special Issue), 93-107.

Lundvall, B., Johnson, B. (1994). The learning economy. Journal of Industry Studies, 1, $23-42$.

Mikuła, B. (2006). Organizacje oparte na wiedzy. Kraków: Wydawnictwo Akademii Ekonomicznej.

Polanyi, M. (1966). The tacit dimension. Garden City, N.Y: Doubleday.

Probst, G., Raub, S., Romhardt, K. (2002). Zarządzanie wiedzą w organizacji. Kraków: Oficyna Ekonomiczna.

Roland-Lévy, Ch. (2004). W jaki sposób nabywamy pojęcia i wartości ekonomiczne? In: T. Tyszka (ed.), Psychologia ekonomiczna. Gdańsk: GWP.

Spender, J.C. (1996). Making knowledge the basis of a dynamic theory of the firm. Strategic Management Journal, 17 (Winter Special Issue), 45-62.

Sveiby, K.E. (1997). Tacit knowledge. Retrieved from www.sveiby.com/articles/Polanyi.html.

Tiwana, A. (2003). Przewodnik po zarządzaniu wiedzą, e-biznes i zastosowania CRM. Warszawa: Wydawnictwo Placet.

Wiig, K.M. (1996). The intelligent enterprise and knowledge management. London: Knowledge Research Institute, Inc.

Zaleśkiewicz, T. (2011). Psychologia ekonomiczna. Warszawa: Wydawnictwo Naukowe PWN.

Cite this article aS: Sokół, A, Figurska, I. (2018). The state of economic knowledge and its importance in the opinion of young Poles. European Journal of Service Management, 4 (28/1), 289-296. DOI: 10.18276/ejsm.2018.28/1-36. 